$\mathrm{DOI}$

Удк 631.89:631.95:635.21

ЭФФЕКТИВНОСТЬ ПРИМЕНЕНИЯ ОРГАНОМИНЕРАЛЬНОЙ СИСТЕМЫ

УДОБРЕНИЙ С ЦЕЛЬЮ ИНАКТИВАЦИИ ТЯЖЕЛЫХ МЕТАЛЛОВ

ПРИ ВЫРАЩИВАНИИ КАРТОФЕЛЯ В СТЕПНОЙ ЗОНЕ САМАРСКОГО ЗАВОЛЖЬЯ

Чернякова Галина Игнатьевна, аспирант кафедры «Садоводство, ботаника и физиология растений», ФГБОУ ВО Самарский ГАУ.

446442, Самарская область, п.г.т. Усть-Кинельский, ул. Учебная, 2.

E-mail: volgozem5@mail.ru

Троц Наталья Михайловна, д-р с.-х. наук, проф. кафедры «Садоводство, ботаника и физиология растений», ФГБОУ ВО Самарский ГАУ.

446442, Самарская область, п.г.т. Усть-Кинельский, ул. Учебная, 2.

E-mail: troz_shi@mail.ru

Костин Яков Владимирович, д-р с.-х. наук, проф. кафедры «Лесное дело, агрохимия и экология», ФГБОУ ВО Рязанский ГАТУ им. П. А. Костычева.

390044, г. Рязань, ул. Костычева, 1.

E-mail: yakov.kostin.52@mail.ru

Ключевые слова: почва, удобрения, навоз, картофель, металлы, коэффициент, урожайность.

Цель исследований - повышение продуктивности картофеля за счет применения органоминеральной системы удобрений. Исследования проводились на полях севооборота под плантациями картофеля сортов Арника и Ароза. Расстояние между гребнями $75 \mathrm{~cm}$, высота гребня 18-20 см, расстояние между посадочными местами в ряду- 24 см. В применяемом севообороте предшественником для картофеля служил чистый (черный) пар. Объект изучения - почва верхнего пахотного горизонта (0-30 см). Представлены результаты применения системы удобрений почвы под растения сортового картофеля, состоящей из фоновой дозы минеральных удобрений N120P150K300 и добавления навоза в дозах 20 т/га и 60 т/га на четырех опытных участках площадью 210 га. Определение содержания тяжелых металлов проводили в сертифицированной лаборатории ФГУ «Станция агрохимической службы «Самарская» методом атомноабсорбционной спектроскопии. По результатам содержания подвижных форм тяжелых металлов в почве рассчитали коэффициент концентрации, который показал, что фактическое среднее значение превышает фоновый уровень. Коэффициент концентрации свинца - 1,6 - указывает на накопление элемента на исследуемом участке. Органоминеральная система удобрений N120P150К300+навоз 60 т/га позволяет восстановить баланс гумуса в исследованном черноземе обыкновенном, получить прибавку урожая 4,1-8,9 т/га, оказывает влияние на снижение содержания в почве валового содержания тяжелых металлов: Cd - в 1,2-1,4 раза; Сu-в 1,1-1,2 раза, $\mathrm{Pb}, \mathrm{Zn}, \mathrm{Mn}$ и Fe - в 1,1 раза по сравнению с контрольным участком. В варианте опыта N120 Р150 К300 + навоз 60 т/га уменьшается подвижность свинца до 3,9\%, меди, цинка, железа - менее, чем на $1 \%$, возрастает подвижность кадмия на 3,4-5,7 \%. 


\section{EFFICIENCY OF APPLICATION OF ORGANOMINERAL FERTILIZERS IN ORDER OF HEAVY METALS INACTIVATION WHEN GROWING POTATOES IN SAMARA VOLGA STEPPE ZONE}

G. I. Chernyakova, Graduate Student of the Department «Gardening, Botany and Physiology of Plants», FSBEI HE Samara State Agrarian University.

446442, Samara region, settlement Ust-Kinelskiy, Uchebnaya street, 2.

E-mail: troz_shi@mail.ru

N. M. Trots, Doctor of Agricultural Sciences, Professor of the Department «Gardening, Botany and Physiology of Plants», FSBEI HE Samara State Agrarian University.

446442, Samara region, settlement Ust-Kinelskiy, Uchebnaya street, 2.

E-mail: troz_shi@mail.ru

Y. V. Kostin, Doctor of Agricultural Sciences and Professor of the department «Forestry, Agricultural Chemistry and Ecology», FSBEI HE Ryazan State Agro-technological University named after P. A. Kostychev.

390044, Ryazan, Kostychev street, 1.

E-mail: yakov.kostin.52@mail.ru

Keywords: soil, fertilizers, manure, potatoes, metals, coefficient, yield.

The aim of the research is increasing the productivity of potatoes via the use of organic fertilizers. Research was carried out on crop rotation fields with potato plantations of Arnica and Arosa breeds. The distance between the ridges is $75 \mathrm{~cm}$, the ridge height is $18-20 \mathrm{~cm}$, and the distance between seats in a row is $24 \mathrm{~cm}$. In the applied crop rotation, potato was planted on fallow steam. The object of study is the soil of the upper farm field $(0-30 \mathrm{~cm})$. The results of applying programmed soil fertilizers for potato plants consisting of background mineral fertilizers N120P150K300 and manure in doses of $20 \mathrm{t} / \mathrm{ha}$ and $60 \mathrm{t} / \mathrm{ha}$ for four experimental plots with an area of 210 ha are presented. Determination of heavy metal content was performed within the certified laboratory of the Federal state University «Station of agrochemical service "Samara» by atomic absorption spectroscopy. Based on the results of heavy metals mobile forms in the soil, a concentration coefficient was calculated, which showed that the actual average value exceeds the background level. The lead concentration coefficient amounting to $1.6-$ indicates the accumulation of the element on the research area. Organo-mineral fertilizer N120P150K300+manure $60 \mathrm{t} /$ ha allows you to restore the balance of mould on the research ordinary Chernozem, get an increase in yield of 4.1-8.9 $\mathrm{t} / \mathrm{ha}$, has an effect on reducing the content of gross heavy metals in the soil: $\mathrm{Cd}-$ by 1.2-1.4 times; $\mathrm{Cu}-1.1-1.2$ times, $\mathrm{Pb}, \mathrm{Zn}, \mathrm{Mn}$ and $\mathrm{Fe}-1.1$ times compared to the control area. Within the experiment N120 P150K300 + manure $60 \mathrm{t} /$ ha lead mobility reduces to $3.9 \%$, copper, zinc, iron-less than by $1 \%$, cadmium mobility increases by $3.4-5.7 \%$. 
Картофель является важнейшей продовольственной культурой во всех агроэкологических зонах Самарской области. Для степной зоны области, как и для центральной и южной, представляет опасность уменьшение содержания гумуса в почвах, макроэлементов, загрязнение токсичными метаболитами, тяжелыми металлами $[3,4,5]$.

Следствием указанных процессов является снижение продуктивности картофеля, получение низкокачественной продукции [6].

Проблема повышения качества и величины урожая решается за счет процессов биологизированной системы земледелия, которые, наряду с другими методами, предполагают использование ресурсов традиционных органических удобрений $[1,7]$.

Цель исследования - повышение продуктивности картофеля за счет применения органоминеральной системы удобрений.

Задача исследований - оценить действие органоминеральной системы удобрений на снижение аккумуляции тяжелых металлов (свинца, кадмия, меди, цинка, кобальта, марганца, железа) в почве под плантациями картофеля.

Материалы и методы исследований. Исследования проводились в 2003, 2011, 2012 -2014 гг. на полях хозяйства, расположенного в южной агроклиматической зоне Самарской области. В 20122014 гг. проводился эксперимент по изучению эффективности влияния минеральных удобрений и их сочетания с органическим удобрением (навозом) на аккумуляцию тяжелых металлов (кадмия, свинца, меди, цинка, марганца, хрома, железа) почвами под плантациями картофеля. В опытах исследовались почвы под двумя сортами: Арника и Ароза (фактор В). Эксперимент проводился в трехкратной повторности по схеме: I - контроль N120P150K300, II - минеральные удобрения N120P150K300 + навоз в дозе 20 т/га; III - минеральные удобрения N120P150K300 + навоз в дозе 60 т/га (фактор A).

Минеральные удобрения под картофель вносились до его посадки. Полная доза калийных удобрений (KCL 60\%) вносилась осенью под нарезку гребней в один приём разбрызгивателем навесным Rauch MDS 935 на тракторе Д/Д 6920,Д/Д 6130. Весной одновременно с посадкой производилось внесение аммофоса (N12P52), затем через10-15 дней перед окучиванием производилась подкормка азотным удобрением сульфатом аммония N21 S24.

Органические удобрения вносились только на учетные площадки, отведенные под исследования. Внесение органических удобрений производили перед фрезерованием на подготовленную для посадки почву. Удобрения равномерно распределяли по участку граблями с последующей заделкой в почву в течение 3-5 часов после разбрасывания при помощи фрезы. Под картофель, особенно ранних сортов, вносили только перепревший или полуперепревший навоз.

Площадь полевого севооборота 840 га, в границах которого четыре опытных участка площадью 210 га. В исследованиях применен неспециализированный севооборот, когда картофель возвращается на одно и то же поле не ранее чем через 4 года.

Учетные площадки имеют форму квадрата со стороной 30 м (40 рядов), площадь 900 м2 (30х30). При формировании учетной площадки была принята схема: 10 рядов - контроль, 10 рядов вариант с внесением NPK + навоз 20 т/га, 10 рядов - вариант с NPK + навоз 60 т/га.

В применяемом севообороте предшественником для картофеля служил чистый (черный) пар. Расстояние между гребнями 75 см, высота гребня 18-20 см, расстояние между посадочными местами в ряду $24 \mathrm{~cm}$. 
Расчет площадей под опытные делянки произведен с учетом параметров посадки и составляют: общая площадь - 900 м2, вариант с внесением NPK - 225 м2 (7,5х30); с NPK + навоз - 225 м2 (7,5х30); контроль - 225 м2 (7,5×30); 2 междурядья - 112,5 м2 (3,5×30).

Объект изучения - почва верхнего пахотного горизонта (0-30 см) под плантациями сортового картофеля. Образцы почв отбирались в соответствии с общепринятыми методиками [5].

Определение содержания тяжелых металлов проводилось методом атомно-абсорбционной спектроскопии в сертифицированной лаборатории ФГУ «Станция агрохимической службы «Самарская».

Результаты исследований. Обследование почвы на содержание тяжелых металлов выявило, что концентрация их валовых и подвижных форм в почве в средних значениях находится ниже норм ПДК и ОДК (табл. 1).

Таблица 1

Содержание валовых форм тяжелых металлов в пахотном горизонте почвы под участками сортового картофеля, 2003-2011 гг.

\begin{tabular}{|c|c|c|c|c|c|c|}
\hline \multirow{2}{*}{$\begin{array}{l}\text { Годы } \\
\text { исследований }\end{array}$} & \multicolumn{6}{|c|}{ Элемент, мг/кг } \\
\hline & $\mathrm{Pb}$ & $\mathrm{Cd}$ & $\mathrm{Zn}$ & $\mathrm{Mn}$ & $\mathrm{Fe}$ & $\mathrm{Cu}$ \\
\hline 2003 & 10,3 & 0,66 & 41,4 & 440,0 & 10923 & 14,0 \\
\hline 2011 & 8,9 & 0,05 & 48,9 & 870,1 & 14648 & 17,2 \\
\hline$\Phi \mathrm{OH}^{*}$ & 4,2 & 0,66 & 25,1 & 625,1 & 10923 & 23,8 \\
\hline пДК** & 30,0 & 2,0 & 100 & 1500 & - & 55,0 \\
\hline
\end{tabular}

Примечание: * - по данным АО «ВолгоНИИгипрозем», ** - по данным Н. В. Прохоровой [2].

Результаты полученных анализов: в содержании валовых форм тяжелых металлов в пахотном слое почвы за период с 2003 года по 2011 год произошли изменения в сторону увеличения: Zn и $\mathrm{Cu}$ в 1,2 раза, $\mathrm{Mn}$ в 2 раза, Fe в 1,3 раза; в сторону уменьшения - Pb в 1,2 раза, $\mathrm{Cd}$ в 13,2 раза. По сравнению с фоном, валовое содержание тяжелых металлов повысилось в 1,3-2,1 раза, кроме Сu и Cd, содержание которых в исследуемых почвах в динамике по годам исследований снизилось: в 13,2 раза Cd и в 1,4 раза Сu. Снижение уровня валовых форм элементов можно объяснить переводом их в подвижные формы, вымыванием при орошении в нижележащие горизонты, поглощением растениями.

Валовые значения характеризуют общую загрязненность почвы, а степень доступности элементов для почвенного питания отражают их подвижные формы.

Среднее содержание за период 2012-2014 гг. подвижных форм изученных тяжелых металлов не превышает предельно допустимой концентрации (табл. 2).

Таблица 2

Среднее содержание подвижных форм тяжелых металлов в почве, мг/кг

\begin{tabular}{|l|l|l|l|l|l|l|}
\hline Годы исследований & $\mathrm{Pb}$ & $\mathrm{Cd}$ & $\mathrm{Zn}$ & $\mathrm{Mn}$ & $\mathrm{Fe}$ & $\mathrm{Cu}$ \\
\hline 2011 & 1,15 & 0,023 & 0,13 & 10,76 & 4,42 & 0,05 \\
\hline
\end{tabular}




\begin{tabular}{|l|l|l|l|l|l|l|}
\hline 2012 & 0,44 & 0,050 & 0,19 & 11,91 & 3,32 & 0,12 \\
\hline 2013 & 0,43 & 0,050 & 0,18 & 11,70 & 3,53 & 0,13 \\
\hline 2014 & 0,53 & 0,050 & 0,23 & 15,16 & 2,18 & 0,06 \\
\hline Среднее значение & 0,64 & 0,043 & 0,18 & 12,38 & 3,36 & 0,09 \\
\hline ФОН & 0,4 & 0,037 & 0,40 & 35,0 & 7,67 & 0,13 \\
\hline Кс & 1,60 & 0,043 & 0,45 & 0,35 & 0,44 & 0,69 \\
\hline ПДК & 6,0 & 0,10 & 23,0 & 140,0 & - & 3,0 \\
\hline
\end{tabular}

Для выявления степени загрязнения почвы используется общепринятый коэффициент концентрации Кс. Расчет коэффициентов концентрации показал, что фактическое содержание элементов в почве превышает фоновое значение. Значительное превышение Кс свинца - 1,6 указывает на накопление элемента на исследуемом участке, также выявлено незначительное превышение кадмия $(0,043)$ и цинка $(0,45)$, что также указывает на накопление на исследуемом участке. По рассчитанным значениям коэффициентов концентрации подвижной формы в почве изученные металлы представлены следующим убывающим рядом: $\mathrm{Pb}(1,60)<\mathrm{Cu}(0,69)<\mathrm{Zn}(0,45)<$ Fe $(0,44)<\mathrm{Mn}(0,35)<\mathrm{Cd}(0,043)$.

Эффективность доз органических удобрений (навоз КРС) 20 т/га и 60 т/га в сочетании с минеральными удобрениями N120 P150 К300 рассчитывалась из расчета потребности картофеля в органических удобрениях: 1) Расходная часть статьи баланса = 210 га ×1,7 т = 357 т/га; 2) Приходная часть статьи баланса $=210$ га $\times 0,15 \mathrm{~T}=31,5 \mathrm{~T} / \mathrm{ra}$; 3) Баланс $=31,5 \mathrm{~T} / \mathrm{ra}-357 \mathrm{~T} / \mathrm{ra}=-325,5$ т/га; 4) Потребность в органических удобрениях $=-325,5: 0,1=-3255$ т. В расчете на 1 га = -3255 : $210=-15,5 \mathrm{~T} /$ га.

Полученная расчетным путем норма внесения органических удобрений 15,5 т/га под картофель позволяет восстановить баланс гумуса.

Внесение органического удобрения под сорт Арника на исследуемом участке привело к плавному снижению содержания в почве тяжелых металлов (TM) в вариантах опыта N120 P150 K300 + навоз 20 т/га и N120 P150 K300 + навоз 60 т/га: Cd - в 1,4 раза; Сu - в 1,1-1,2 раза; $\mathrm{Fe}$ - в 1,1 раза по отношению к контролю N120 P150 К300 (табл. 3). Отмечено увеличение содержания в почве Pb, Zn и Mn в 1,1 раза в варианте опыта N120 P150 К300 + навоз 60 т/га по сравнению с контрольной площадкой. На опытных участках под сортом Ароза при внесении органических удобрений (навоз KPC) в варианте опыта N120 P150 К300 +навоз 60 т/га в почве произошло уменьшение содержания всех исследуемых элементов: $\mathrm{Pb}, \mathrm{Zn}, \mathrm{Mn}$ и $\mathrm{Fe}$ - в 1,1 раза, $\mathrm{Cd}$ и Сu - в 1,2 раза по сравнению с контрольным участком. Максимальное снижение при внесении в почву органических удобрений (навоз КРС) произошло в варианте опыта N120 P150 К300 + навоз 60 т/га под сортами Арника и Ароза.

По сравнению с фоном валовое содержание тяжелых металлов выше во всех вариантах опыта: $\mathrm{Pb}$ в 2,1-2,3 раза (максимальное превышение - в 2,3 раза - в варианте опыта N120 P150 K300 + навоз 20 т/га), Zn в 1,6-2,2 раза, Fe в 1,5-1,9 раза (максимальное превышение - в 1,9 раза - в варианте опыта N120 P150 K300 + навоз 20 т/га).

Содержание подвижных форм изученных тяжелых металлов в почве при использовании органоминеральной системы не превышает предельно допустимой концентрации (табл. 4). 
Содержание валовой формы тяжёлых металлов в почве под урожаем картофеля при различных дозах удобрений, 2012-2014 гг.

\begin{tabular}{|c|c|c|c|}
\hline \multirow{2}{*}{ Вариант опыта } & \multicolumn{3}{|l|}{ Сорт Арника } \\
\hline & $\mathrm{Pb}, \mathrm{Mr} / \mathrm{Kг}$ & $\mathrm{Cd}, \mathrm{Mг} / \mathrm{кг}$ & $\mathrm{Cu}, \mathrm{мг} / \mathrm{kг}$ \\
\hline N120P150K300 & $\frac{8,98 \pm 0,86}{7,27-9,89} 1,49$ & $\frac{0,49 \pm 0,03}{0,34-0,44} 0,05$ & $\frac{12,60 \pm 1,77}{9,05-14,47} 3,07$ \\
\hline $\begin{array}{l}\text { N120P150К300 } \\
+ \\
\text { навоз } 20 \text { т/га }\end{array}$ & $\frac{9,44 \pm 0,42}{8,68-10,12} 0,73$ & $\frac{0,34 \pm 0,07}{0,20-0,42} 0,12$ & $\frac{11,56 \pm 1,52}{8,52-13,27} 2,64$ \\
\hline $\begin{array}{l}\text { N120P150K300 } \\
+ \\
\text { навоз } 60 \text { т/га }\end{array}$ & $\frac{9,64 \pm 0,32}{9,02-10,02} 0,54$ & $\frac{0,34 \pm 0,06}{0,22-0,40} 0,10$ & $\frac{10,83 \pm 1,47}{7,88-12,33} 2,55$ \\
\hline$\Phi \mathrm{OH}$ & 4,2 & 0,66 & 23,8 \\
\hline ПДК & 30,00 & 2,00 & 55,00 \\
\hline Вариант опыта & $\mathrm{Zn}, \mathrm{Mr} / \mathrm{kг}$ & $\mathrm{Mn}, \mathrm{Mr} / \mathrm{Kr}$ & $\mathrm{Fe}, \mathrm{мг} / \mathrm{kr}$ \\
\hline N120P150K300 & $\frac{52,00 \pm 4,52}{47,37-61,04} 7,83$ & $\frac{338,00 \pm 8,84}{320,37-347,96} 15,31$ & $\frac{20264,00 \pm 2078,49}{16139,61-22776,11} 3600,05$ \\
\hline $\begin{array}{l}\text { N120P150К300 } \\
+ \\
\text { навоз } 20 \text { т/га }\end{array}$ & $\frac{54,20 \pm 1,60}{52,44-57,40} 2,77$ & $\frac{365,33 \pm 16,26}{343,23-397,06} 28,18$ & $\frac{20496,66 \pm 2701,40}{15146,77-23824,91} 4678,97$ \\
\hline $\begin{array}{l}\text { N120P150K300 } \\
+ \\
\text { навоз } 60 \text { т/га }\end{array}$ & $\frac{55,20 \pm 2,46}{52,48-60,11} 4,26$ & $\frac{348,67 \pm 15,82}{321,13-375,94} 27,40$ & $\frac{19638,33 \pm 2187,71}{15264,22-21918,01} 3737,12$ \\
\hline$\Phi \mathrm{OH}$ & 25,1 & 625,1 & 10923 \\
\hline ПДК & 100,00 & 1500,00 & - \\
\hline \multirow{2}{*}{ Вариант опыта } & \multicolumn{3}{|l|}{ Сорт Ароза } \\
\hline & $\mathrm{Pb}, \mathrm{Mr} / \mathrm{Kr}$ & $\mathrm{Cd}, \mathrm{Mr} / \mathrm{kr}$ & $\mathrm{Cu}, \mathrm{Mr} / \mathrm{kr}$ \\
\hline N120P150K300 & $\frac{9,42 \pm 0,17}{9,06-9,60} 0,30$ & $\frac{0,36 \pm 0,09}{0,22-0,53} 0,16$ & $\frac{11,95 \pm 1,58}{9,23-14,69} 2,73$ \\
\hline $\begin{array}{l}\text { N120P150К300 } \\
+ \\
\text { навоз } 20 \text { т/га }\end{array}$ & $\frac{9,80 \pm 0,42}{9,28-10,62} 0,73$ & $\frac{0,30 \pm 0,05}{0,21-0,35} 0,08$ & $\frac{11,19 \pm 1,08}{9,16-12,86} 1,87$ \\
\hline $\begin{array}{l}\text { N120P150K300 } \\
+ \\
\text { навоз } 60 \text { т/га }\end{array}$ & $\frac{9,32 \pm 0,09}{9,20-9,50} 0,16$ & $\frac{0,31 \pm 0,06}{0,19-0,38} 0,10$ & $\frac{9,86 \pm 0,72}{8,42-10,58} 1,25$ \\
\hline ФОН & 4,2 & 0,66 & 23,8 \\
\hline
\end{tabular}




\begin{tabular}{|c|c|c|c|}
\hline пдк & 30,00 & 2,00 & 55,00 \\
\hline Вариант опыта & $\mathrm{Zn}, \mathrm{Mr} / \mathrm{k}$ & $\mathrm{Mn}, \mathrm{Mr} / \mathrm{Kr}$ & $\mathrm{Fe}, \mathrm{мг/кг}$ \\
\hline N120P150K300 & $\frac{46,0 \pm 2,25}{41,54-48,77} 3,89$ & $\frac{309,5 \pm 15,51}{278,49-325,92} 26,87$ & $\frac{18196,00 \pm 2484,00}{13229,00-20744,00} 4301,61$ \\
\hline $\begin{array}{l}\text { N120P150К300 } \\
+ \\
\text { навоз } 20 \text { т/га }\end{array}$ & $\frac{40,46 \pm 1,69}{38,73-43,84} 2,93$ & $\frac{275,5 \pm 19,95}{238,88-302,39} 34,55$ & $\frac{17186,66 \pm 2433,09}{12320,49-19622,26} 4214,23$ \\
\hline $\begin{array}{l}\text { N120P150K300 } \\
+ \\
\text { навоз } 60 \text { т/га }\end{array}$ & $\frac{41,83 \pm 2,08}{39,13-45,91} 3,59$ & $\frac{295,83 \pm 14,92}{266,37-314,74} 25,85$ & $\frac{16241,66 \pm 2021,41}{12198,85-18266,59} 3500,67$ \\
\hline$\Phi \mathrm{OH}$ & 25,1 & 625,1 & 10923 \\
\hline ПДк & 100,00 & 1500,00 & - \\
\hline
\end{tabular}

Содержание в почве подвижных форм тяжелых металлов по отношению к валовому в процентном выражении неодинаково и колеблется в зависимости от варианта опыта. Содержание подвижной формы свинца составляет 5,3\% от валового (сорт Арника) на контрольной площадке N120P150K300, на опытных делянках произошло снижение до 3,9\% (наибольшее снижение - в варианте опыта N120 P150 K300 + навоз 60 т/га). Менее 1\% от валового выявлено содержание подвижных форм следующих изучаемых элементов тяжелых металлов - Cu, Zn, Fe.

Таблица 4

Содержание подвижной формы тяжёлых металлов в почве под урожаем картофеля при различных дозах удобрений, 2012-2014 гг.

\begin{tabular}{|c|c|c|c|}
\hline \multirow{2}{*}{ Вариант опыта } & \multicolumn{3}{|l|}{ Сорт Арника } \\
\hline & $\mathrm{Pb}, \mathrm{Mr} / \mathrm{kг}$ & $\mathrm{Cd}, \mathrm{Mг} / \mathrm{kг}$ & $\mathrm{Cu}, \mathrm{Mr} / \mathrm{kr}$ \\
\hline N120P150K300 & $\frac{0,48 \pm 0,28}{0,16-1,03} 0,48$ & $\frac{0,054 \pm 0,01}{0,045-0,069} 0,01$ & $\frac{0,14 \pm 0,05}{0,09-0,24} 0,09$ \\
\hline \% к валовому & 5,3 & 11,0 & 1,1 \\
\hline $\begin{array}{l}\text { N120P150K300 } \\
+ \\
\text { навоз } 20 \text { т/га }\end{array}$ & $\frac{0,56 \pm 0,03}{0,50-0,61} 0,06$ & $\frac{0,052 \pm 0,01}{0,046-0,064} 0,01$ & $\frac{0,05 \pm 0,01}{0,04-0,07} 0,01$ \\
\hline \% к валовому & 5,9 & 15,3 & 0,4 \\
\hline $\begin{array}{l}\text { N120P150K300 } \\
+ \\
\text { навоз } 60 \text { т/га }\end{array}$ & $\frac{0,38 \pm 0,06}{0,32-0,48} 0,08$ & $\frac{0,053 \pm 0,01}{0,045-0,063} 0,01$ & $\frac{0,04 \pm 0,01}{0,03-0,06} 0,02$ \\
\hline \% к валовому & 3,9 & 15,6 & 0,4 \\
\hline$\Phi \mathrm{OH}$ & 0,40 & 0,037 & 0,13 \\
\hline
\end{tabular}




\begin{tabular}{|c|c|c|c|}
\hline ПДк & 6,0 & 0,10 & 3,0 \\
\hline Вариант опыта & Zn, мг/кг & $\mathrm{Mn}, \mathrm{Mr} / \mathrm{kr}$ & $\mathrm{Fe}, \mathrm{мг/кг}$ \\
\hline N120P150K300 & $\frac{0,28 \pm 0,04}{0,21-0,35} 0,07$ & $\frac{14,70 \pm 8,41}{6,08-31,53} 14,58$ & $\frac{3,50 \pm 0,84}{2,58-5,19} 1,46$ \\
\hline \% к валовому & 0,5 & 4,3 & 0,02 \\
\hline $\begin{array}{l}\text { N120P150К300 } \\
+ \\
\text { навоз } 20 \text { т/га }\end{array}$ & $\frac{0,30 \pm 0,09}{0,15-0,45} 0,15$ & $\frac{13,32 \pm 6,37}{6,49-26,06} 11,04$ & $\frac{3,86 \pm 1,01}{2,48-5,80} 1,73$ \\
\hline \% к валовому & 0,6 & 3,6 & 0,02 \\
\hline $\begin{array}{l}\text { N120P150К300 } \\
+ \\
\text { навоз } 60 \text { т/га }\end{array}$ & $\frac{0,46 \pm 0,02}{0,44-0,49} 0,02$ & $\frac{14,60 \pm 6,54}{7,03-27,63} 11,34$ & $\frac{3,68 \pm 0,71}{2,44-4,91} 1,23$ \\
\hline \% к валовому & 0,8 & 4,2 & 0,02 \\
\hline$\Phi$ & 0,40 & 35,00 & 7,67 \\
\hline ПДК & 23,0 & 140,0 & - \\
\hline \multirow{2}{*}{ Вариант опыта } & \multicolumn{3}{|l|}{ Сорт Ароза } \\
\hline & $\mathrm{Pb}, \mathrm{Mr} / \mathrm{kr}$ & $\mathrm{Cd}, \mathrm{Mr} / \mathrm{kг}$ & $\mathrm{Cu}, \mathrm{Mг} / \mathrm{kг}$ \\
\hline N120P150K300 & $\frac{0,30 \pm 0,07}{0,23-0,43} 0,12$ & $\frac{0,044 \pm 0,01}{0,031-0,068} 0,02$ & $\frac{0,11 \pm 0,05}{0,05-0,21} 0,09$ \\
\hline \% к валовому & 3,2 & 12,2 & 0,9 \\
\hline $\begin{array}{l}\text { N120P150K300 } \\
+ \\
\text { навоз } 20 \text { т/га }\end{array}$ & $\frac{0,11 \pm 0,02}{0,09-0,16} 0,04$ & $\frac{0,050 \pm 0,01}{0,037-0,070} 0,02$ & $\frac{0,07 \pm 0,03}{0,03-0,13} 0,05$ \\
\hline \% к валовому & 1,1 & 16,7 & 0,6 \\
\hline $\begin{array}{l}\text { N120P150K300 } \\
+ \\
\text { навоз } 60 \text { т/га }\end{array}$ & $\frac{0,16 \pm 0,02}{0,13-0,21} 0,04$ & $\frac{0,055 \pm 0,01}{0,040-0,064} 0,01$ & $\frac{0,03 \pm 0,01}{0,02-0,02} 0,01$ \\
\hline \% к валовому & 1,7 & 17,7 & 0,3 \\
\hline$\Phi O H$ & 0,40 & 0,037 & 0,13 \\
\hline ПДК & 6,0 & 0,10 & 3,0 \\
\hline Вариант опыта & $\mathrm{Zn}, \mathrm{Mr} / \mathrm{kr}$ & $\mathrm{Mn}, \mathrm{Mr} / \mathrm{Kr}$ & $\mathrm{Fe}, \mathrm{Mr} / \mathrm{kr}$ \\
\hline N120P150K300 & $\frac{0,18 \pm 0,07}{0,11-0,32} 0,12$ & $\frac{13,30 \pm 6,99}{6,28-27,31} 12,13$ & $\frac{2,84 \pm 0,22}{2,41-3,07} 0,37$ \\
\hline \% к валовому & 0,4 & 4,3 & 0,02 \\
\hline
\end{tabular}




\begin{tabular}{|l|l|l|l|}
\hline $\begin{array}{l}\text { N120Р150К300 } \\
+\end{array}$ & $\frac{0,17 \pm 0,07}{0,11-0,28} 0,10$ & $\frac{12,23 \pm 6,21}{5,98-24,64} 10,75$ & $\frac{1,14 \pm 0,27}{0,84-1,69} 0,48$ \\
\hline$\%$ к валовому 20 т/га & 0,4 & 4,4 & 0,07 \\
\hline $\begin{array}{l}\text { N120Р150К300 } \\
\text { навоз 60 т/га }\end{array}$ & $\frac{0,41 \pm 0,03}{0,38-0,47} 0,05$ & $\frac{14,47 \pm 5,91}{8,11-26,27} 10,24$ & $\frac{2,55 \pm 0,33}{1,90-3,01} 0,58$ \\
\hline$\%$ к валовому & 1,0 & 4,9 & 0,02 \\
\hline ФОН & 0,40 & 35,00 & 7,67 \\
\hline ПДК & 23,0 & 140,0 & - \\
\hline
\end{tabular}

Содержание подвижной формы Сd от валового колеблется - от 11\% на контрольной площадке N120 P150 K300 до 15,6\% в варианте опыта N120 P150 K300 + навоз 60 т/га (сорт Арника); от 12,2 \% на контрольной площадке N120 P150 K300 до 17,7 \% в варианте опыта N120 P150 K300 +навоз 60 т/га (сорта Ароза). Наблюдается некоторое превышение фоновых значений по накоплению цинка в 1,15 раза в варианте опыта N120 P150 К300 + навоз 60 т/га, меди в 1,07 раз и свинца в 1,4 раза.

Наблюдается незначительное превышение фоновых значений: по накоплению свинца в 1,2 раза, кадмия в 1,4 раза, меди в 1,1 раза на контрольной площадке N120 P150 К300. В варианте опыта N120 P150 K300 + навоз 20 т/га наблюдается превышение фосфора в 1,4 раза, кадмия в 1,4 раза (по сортам Арника и Ароза), в варианте опыта N120 P150 K300 + навоз 60 т/га превышение кадмия в 1,4-1,5 раза, цинка в 1,2 раза (незначительное превышение фоновых уровней указывает на то, что эти металлы являются рассеянными в почве).

В среднем за период с 2012 по 2014 годы увеличение дозы навоза способствовало увеличению урожайности картофеля (табл. 5).

Таблица 5

Урожайность картофеля при различных дозах удобрений, 2012-2014 гг.

\begin{tabular}{|c|c|c|c|c|c|c|}
\hline \multirow{3}{*}{$\begin{array}{l}\text { Вариант } \\
\text { опыта }\end{array}$} & \multirow{3}{*}{2012} & \multirow{3}{*}{2013} & \multirow{3}{*}{2014} & \multicolumn{3}{|l|}{ Среднее } \\
\hline & & & & \multirow{2}{*}{$\begin{array}{l}\text { Урожайность } \\
\text { т/га }\end{array}$} & \multicolumn{2}{|c|}{ Прибавка } \\
\hline & & & & & т/га & $\%$ \\
\hline \multicolumn{7}{|l|}{ Сорт Ароза } \\
\hline $\begin{array}{l}\text { N120P150K30 } \\
0\end{array}$ & 30,8 & 28,5 & 33,0 & 30,8 & - & - \\
\hline $\begin{array}{l}\text { N120P150K30 } \\
0+ \\
\text { навоз } 20 \text { т/га }\end{array}$ & 31,7 & 29,4 & 33,9 & 31,6 & 0,9 & 2,8 \\
\hline $\begin{array}{l}\text { N120P150K30 } \\
0+ \\
\text { навоз } 60 \text { т/га }\end{array}$ & 39,7 & 37,4 & 41,9 & 39,7 & 8,9 & 22,4 \\
\hline Сорт Арника & & & & & & \\
\hline
\end{tabular}




\begin{tabular}{|l|l|l|l|l|l|l|}
\hline $\begin{array}{l}\text { N120Р150К30 } \\
0\end{array}$ & 30,8 & 28,5 & 33,0 & 30,8 & - & - \\
\hline $\begin{array}{l}\text { N120Р150К30 } \\
0+ \\
\text { навоз 20 т/га }\end{array}$ & 32,2 & 29,9 & 34,4 & 32,2 & 1,4 & 4,3 \\
\hline $\begin{array}{l}\text { N120Р150К30 } \\
0+ \\
\text { навоз 60 т/га }\end{array}$ & 34,9 & 32,7 & 37,2 & 34,9 & 4,1 & 11,7 \\
$\begin{array}{l}\text { НСР 0,5 (факт. } \\
\text { А) }\end{array}$ & 0,9 & 0,7 & 0,6 & & \\
НСР 0,5 (факт. & 1,8 \\
В) \\
$\begin{array}{l}\text { НСР 0,5 (факт. } \\
\text { АВ) }\end{array}$ & 1,1 & 0,9 & & \\
\hline
\end{tabular}

При дозе внесения органических удобрений 60 т/га выявлена значительная прибавка к урожаю, при внесении 20 т/га она гораздо меньше, так как часть внесенного навоза - 15,5 т/га - идет на восстановление отрицательного баланса гумуса и только 0,5 т/га остается на создание прибавки к урожаю.

Установлено, что урожайность исследованных сортов картофеля преимущественно повышается при внесении к основному фону N120P150К300 органической добавки в виде навоза в дозе 60 т/га.

Заключение. По рассчитанным коэффициентам концентрации изученные металлы в исследуемых черноземах образуют убывающий ряд: $\mathrm{Pb}(1,60)<\mathrm{Cu}(0,69)<\mathrm{Zn}(0,45)<\mathrm{Fe}(0,44)<\mathrm{Mn}(0,35)<\mathrm{Cd}$ $(0,043)$.Проведенные исследования позволили установить, что органоминеральная система удобрений N120P150K300+навоз 60 т/га позволяет восстановить баланс гумуса в исследованном черноземе обыкновенном, получить прибавку урожая 4,1-8,9 т/га, оказывает влияние на снижение содержания в почве валового содержания тяжелых металлов: Cd - в 1,2-1,4 раза; Сu - в 1,1-1,2 раза, Pb, Zn, Mn и Fe - в 1,1 раза по сравнению с контрольным участком. В варианте опыта N120 P150 К300 + навоз 60 т/га уменьшается подвижность свинца до 3,9\%, меди, цинка, железа менее, чем на 1\%, возрастает подвижность кадмия на 3,4-5,7\%

\section{Библиографический список}

1. Крючков, М. М. Инновационные элементы агротехнологий возделывания картофеля в Нечерноземной зоне России : монография / М. М. Крючков, Д. В. Виноградов, Н. В. Бышов [и др.]. - Рязань : РГАТУ им. П. А. Костычева, 2018. - 181 с.

2. Прохорова, Н. В. Территориальные особенности распределения тяжелых металлов в почвах Самарской области / Н. В. Прохорова, Н. М. Матвеев // Известия Самарского научного центра Российской академии наук. - 2000. - Т. 2, № 2 - С. 306-310.

3. Троц, Н. М. Агроэкологический анализ интродуцированных сортов картофеля, возделываемых в условиях степной зоны Самарского Заволжья / Н. М. Троц, Г.И.Чернякова, А. А. Пахомов // 
Инновационные достижения науки и техники АПК : сборник научных трудов Международной научно-практической конференции. - Кинель : РИО Самарского ГАУ, 2019. - С. 96-100.

4. Троц, Н. М. Тяжелые металлы в агроландшафтах Самарской области : монография / Н. М. Троц, Н. В. Прохорова, В. Б. Троц [и др.]. - Кинель : РИО Самарской ГСХА, 2018. - 220 с.

5. Троц, Н. М. Экологическая устойчивость в посевах основных групп сельскохозяйственных культур в Самарской области / Н. М. Троц, Г. И. Чернякова, С. В. Ишкова, А. В. Батманов // Аграрная Россия. - 2017. - № 5 - С. 38-44.

6. Троц, Н. М. Особенности накопления тяжелых металлов перспективными сортами картофеля, возделываемыми в южной зоне Самарской области / Н. М. Троц, Черняков А. И. // Известия Самарской ГСХА. - 2013. - № 4. - С. 17-21.

7. Чекмарев, П. А. Система удобрений в условиях биологизации земледелия / П. А. Чекмарев, С. В. Лукин // Достижения науки и техники АПК. - 2012. - № 12 - С. 10-12.

\section{References}

1. Kryuchkov, M. M., Vinogradov, D. V., Byshov, N. V., Lukyanova, O. V., Stupin, A. S., Sokolov, A. A., Potapova, L. V., \& Trots, N. M. (2018). Innovacionniie elementi agrotekhnologii vozdelivaniia kartofelia v Nechernozemnoi zone Rossii [Innovative elements of agricultural technologies of potato cultivation in the Non-Black Earth Zone of Russia]. Ryazan: PC RSATU named after P. A. Kostycheva [in Russian].

2. Prokhorova, N. V., \& Matveev, N. M. (2000). Territorialinie osobennosti raspredeleniia tiazhelikh metallov v pochvah Samarskoi oblasti [Territorial features of the distribution of heavy metals in soils of the Samara region].Izvestiia Samarskogo nauchnogo centra Rossiiskoi akademii nauk - Izvestia of Samara Scientific Center of the Russian Academy of Sciences, 2, 2, 306-310 [in Russian].

3. Trotz, N. M., Chernyakova, G. I., \& Pakhomov, A. A. (2019). Agroekologicheski I analiz introducirovannikh sortov kartofelia, vozdelivaemikh v usloviiakh stepnoi zoni Samarskogo Zavolzhiia. [Agroecological analysis of introduced potato varieties cultivated in the steppe zone of the Samara Trans-Volga region]. Innovative Achievements of Science and Technology of the Agro-Industrial Complex '19: sbornik nauchnikh trudov Mezhdunarodnoi nauchno-prakticheskoi konferencii - collection of scientific papers of the International scientific-practical conference. (pp. 96-100). Kinel [in Russian].

4. Trots, N. M., Prokhorova, N. V., Trots, V. B., Akhmatov, D. A., Chernyakova, G. I., Gorshkova, O. V, Vinogradov, D. V., \& Kostin, Y. V. (2018). Tiazheliie metalli v agro-landshaftakh Samarskoi oblasti [Heavy metals in the agro- landscapes of the Samara region]. Kinel: PC Samara State Agricultural Academy [in Russian].

5. Trots, N. M., Chernyakova, G. I., Ishkova, S. V., \& Batmanov, A. V. (2017). Ekologicheskaia ustoichivost $\checkmark$ posevah osnovnikh grup seliskohoziaistvennikh kulitur v Samarskoi oblasti [Ecological sustainability in the crops of the main groups of crops in the Samara region]. Agrarnaia Rossiia - Agrarnaya Rossiya, 5, 38-44 [in Russian].

6. Trot, N. M., \& Chernyakov A. I. (2013). Osobennosti nakopleniia tiazhelikh metallov perspektivnimi sortami kartofelia, vozdelivaemimi v juzhnoi zone Samarskoi oblasti [Features of the accumulation of heavy metals by promising potato varieties cultivated in the southern zone of the Samara region].Izvestiia Samarskoi gosudarstvennoi selskokhoziaistvennoi akademii - Bulletin Samara state agricultural academy, 4, 17-21 [in Russian]. 
7. Chekmarev, P. A., \& Lukin, S. V. (2012). Sistema udobrenii v usloviiakh biologizacii zemledeliia [The fertilizer system in the conditions of biologization of agriculture]. Dostizheniia nauki I tekhniki APK Achievements of Science and Technology of AICis, 12, 10-12 [in Russian]. 